\title{
Perbaikan Sifat Fisik Tanah Inceptisol dan Pertumbuhan Tanaman Jagung (Zea mays L.) akibat Pemberian Kompos Granul Ela Sagu dan Pupuk Fosfat
}

\author{
The Improvement of Physical Characteristics of Inceptisols and the Response of Maize \\ Due to the Application of Sago Pith Waste Granular Compost and Phosphat Fertilizer \\ on Inceptisols
}

Maimuna La Habi ${ }^{1 *}$, Aminudin Umasangaji ${ }^{1}$

${ }^{1}$ Jurusan Budidaya Pertanian, Fakultas Pertanian, Universitas Pattimura

Jl. Ir. M. Putuhena, Kampus Poka, Ambon 97233

*Corresponding author: maimunalahabi10@gmail.com

\begin{abstract}
Abstrak
Percobaan pot di rumah kaca dirancang untuk mengetahui pengaruh kompos granular limbah empulur sagu dan pupuk fosfat terhadap peningkatan karakteristik fisik Inceptisols dan pertumbuhan jagung. Percobaan menggunakan Rancangan Acak Lengkap faktorial 3 x 3 dengan 3 ulangan. Faktor pertama adalah KGES 0 (tanpa kompos granul ampas sagu), KGES 1 (100 g.pot ${ }^{-}$ ${ }^{1}$ ), dan KGES 2 (200 g.pot ${ }^{-1}$ ) berupa kompos granul limbah empulur sagu; faktor kedua adalah pupuk P0 (tanpa fosfat), P1 (0,326 g.pot $\left.{ }^{-1}\right)$ dan P2 (0,652 g.pot $\left.{ }^{-1}\right)$. Hasil percobaan menunjukkan bahwa pemberian kompos granular limbah empulur sagu dan pupuk fosfor berpengaruh nyata terhadap soil bulk density, particle density, soil porosity, fast drainage pores, slow drainage pores, available water pores, unavailable water pores, total soil- $P$, dan tinggi tanaman. Sedangkan pupuk fosfor tidak berpengaruh nyata terhadap soil bulk density, porosity, slow drainage pores, unavailable water pores, dan tinggi tanaman.
\end{abstract}

Kata kunci: Inceptisols, Jagung, Kompos granular limbah empulur sagu, Pupuk fosfat

\begin{abstract}
Abstrack
A pot experiment in the green house was designed to investigate the effect of sago pith waste granular compost and phosphate fertilizer on the improvement of physical characteristics of Inceptisols and the growth of maize. The experiment used $3 \times 3$ factorial of Completely Randomized Design using 3 replications. The first factor was KGES 0 (no sago pith waste granular compost), KGES 1(100 g.pot $\left.{ }^{-1}\right)$, and KGES 2 (200 g.pot $\left.{ }^{-1}\right)$ of sago pith waste granular compost; the second factor was P0 (no phosfat), P1 (0.326 g.pot $\left.{ }^{-1}\right)$ dan P2 (0.652 g.pot $\left.{ }^{-1}\right)$ of phosphat fertilizer. The experiment showed that the application of sago pith waste granular compost and fosfor fertilizer has significant effect on the soil bulk density, particle density, soil porosity, fast drainage pores, slow drainage pores, available water pores, unavailable water pores, total soil-P, and height of plant. Meanwhile, the fosfor fertilizer has no significant effect on the soil bulk density, porosity, slow drainage pores, unavailable water pores, and height of plant.
\end{abstract}

Keywords: Inceptisols, Maize, Phosphat fertilizer, Sago pith waste granular compost 
Prosiding Seminar Nasional Pembangunan dan Pendidikan Vokasi Pertanian

Politeknik Pembangunan Pertanian Manokwari, 31 Juli 2021

e ISSN : 2774-1982

DOI : https://doi.org/10.47687/snppvp.v2i1.168

\section{PENDAHULUAN}

Semakin meningkatnya jumlah penduduk mengakibatkan semakin terbatasnya lahan pertanian yang subur karena lahan-lahan tersebut telah beralih fungsi menjadi lahan-lahan permukiman guna memenuhi kebutuhan perumahan bagi penduduk (Soemarno, 2002). Oleh karenanya, perluasan lahan pertanian, guna mengupayakan peningkatan produksi pertanian, diarahkan ke wilayah-wilayah tanah masam dan marginal, yang sebagian besar terdiri dari inceptisol (Hairiah et al., 2000).

Berhubungan dengan penambahan bahan organik untuk mengatasi permasalahan yang terjadi pada tanah-tanah masam seperti inceptisol, maka ela sagu dapat menjadi pilihan sebagai salah satu sumber bahan organik yang selama ini belum banyak dimanfaatkan, padahal cukup banyak tersedia di kawasan Timur Indonesia, khususnya di Maluku (Kaya, 2003; La Habi et al, 2007). Ela sagu merupakan limbah sagu yang jika diolah menjadi kompos granul dan granul diperkaya, dapat berperan dalam memperbaiki kesuburan tanah dalam hal ini memperbaiki sifat fisik, kimia tanah dan biologi tanah (La Habi et al., 2007).

Hardjowigeno (2003) mengemukakan bahwa, pemberian bahan organik ke tanah akan berpengaruh terhadap sifat fisik, kimia dan biologi tanah secara simultan, pengaruhnya adalah memperbaiki aerase tanah, menambah kemampuan tanah menahan unsur hara, meningkatkan kapasitas menahan air, meningkatkan daya sanggah tanah, sebagai sumber unsur hara dan sumber energi bagi mikroorganisme tanah. Makin tinggi pemberian bahan organik ke dalam tanah maka berat volume akan semakin rendah, berkisar antara 1,0 sampai 1,3 g.cm ${ }^{-3}$ (De Fretes et al., 1996), menurut Hardjowigeno (2003), kandungan bahan organik yang tinggi menyebabkan tanah mempunyai berat jenis butiran yang rendah, ditambahkan juga oleh Blake (1986) bahwa besarnyan berat jenis tanah pertanian berkisar antar 2,6 sampai 2,7 g.cm ${ }^{-3}$. Islami dan Utomo (1995) mengemukakan bahwa porisitas tanah dipengaruhi oleh susunan partikel dan struktur tanah yang mempunyai peranan bagi daya penyediaan air dan udara serta pertumbuhan akar yang secara langsung berguna bagi pertumbuhan tanaman. Akar tanaman tumbuh dan memanjang diantara ruang padatan tanah (ruang pori), hal yang sama juga terjadi pada pergerakan air, pergerakan hara tanaman dan respirasi akar sehingga diharapkan struktur tanah yang terbentuk akan mempunyai agihan ukuran pori antra lain pori drainase cepat yang berfungsi sebagai pori aerase dan pertumbuhan akar tanaman, pori drainase lambat yang memberi kemudahan bagi pergerakan air dan unsur hara dan pori 
Prosiding Seminar Nasional Pembangunan dan Pendidikan Vokasi Pertanian

Politeknik Pembangunan Pertanian Manokwari, 31 Juli 2021

e ISSN : 2774-1982

DOI : https://doi.org/10.47687/snppvp.v2i1.168

berukuran kecil yaitu pori air tersedia dan pori air tidak tersedia yang berfungsi sebagai tedon air yang dapat digunakan oleh tanaman dalam kurun waktu lama dan tetap berada dalam tingkat kelengasan yang dikehendaki (Islami dan Utomo, 1995). Silahooy (1999) mengemukakan bahwa, pemberian ela sagu dosis 40 ton/ha dengan cara pemberian berbeda mampu meningkatkan pori aerase, pori air tersedia dan porisitas serta menurunkan pori drainase lambat dan berat volume tanah.

Salah satu perbaikan teknologi dalam budidaya jagung yang paling banyak dilakukan adalah pemupukan. Pemupukan merupakan salah satu faktor utama yang menentukan produktifitas tanaman. Ketersediaan pupuk secara tepat dosis dan tepat waktu sering menjadi masalah bagi pertumbuhan jagung. Salah satu usaha untuk meningkatkan $\mathrm{P}$ larutan tanah dan mengurangi kekahatan $\mathrm{P}$ adalah pemberian pupuk $\mathrm{P}$ (Hairiah, 1996; Sufardi 1999). Namun demikian, pemberian pupuk P pada tanah masam seperti inceptisols mengalami pelarutan dengan air tanah sehingga berubah menjadi larutan pupuk dan bereaksi dengan mineral liat dan oksida serta hidroksida aluminium dan besi yang menyebabkan perubahan kembali fosfat dari fase larutan ke bentuk-bentuk yang sukar larut seperti varisit dan strengit (Sample, 1980; Follet et al., 1981; Hartono et al., 2004; Brady dan weil, 2002; Tan, 1998; Tisdale et al., 1993). Peristiwa ini dikenal dengan istilah fiksasi $\mathrm{P}$ atau retensi P. Oleh karena itu pemupukan P pada tanah-tanah masam perlu disertai dengan pemberian bahan amelioran diantaranya bahan organik (Hairiah, 1996; Hairiah et al., 2000; Brady dan Weil, 2002). Hasil Sufardi (1999), menunjukkan bahwa pemberian kompos dan pupuk fosfat pada tanah inceptisols dapat menaikkan $\mathrm{pH}$ tanah, $\mathrm{P}$ tersedia dalam tanah dan serapan $\mathrm{P}$ tanaman jagung.

Jagung merupakan komoditi pangan yang strategis dan menempati urutan kedua setelah padi (Subandi et al., 2004). Berdasarkan data yang diperoleh dari Badan Pusat Statistik (BPS 2004), produktifitas jagung tahun 2004 sebesar 11.162.813 ton mengalami kenaikan sebesar 2,93\% atau 276,371 ton dibandingkan dengan produktifitas 2003 (10.886.442 ton). Sedangkan data yang diperoleh Dinas Pertanian Provinsi Maluku (BPS, 2006) untuk luas panen, rata-rata produksi jagung dari tahun 2001 sampai 2005 secara keseluruhan mengalami kenaikan masing-masing 4754 ha menjadi 6089 ha dan 15,54 kw ha $^{-1}$ menjadi 23,42 $\mathrm{kw} \mathrm{ha}^{-1}$, namun untuk kota Ambon hanya 54 ha dengan rata- rata produksi 23,33 kw ha-1. Dari hasil statistik dapat dilihat bahwa kota Ambon merupakan sentra produksi terendah bila dibandingkan dengan wilayah Maluku lainnya. Dengan demikian, komoditas tersebut ditingkatkan produksinya. Menurut Marsono dan Sigit 
Prosiding Seminar Nasional Pembangunan dan Pendidikan Vokasi Pertanian

Politeknik Pembangunan Pertanian Manokwari, 31 Juli 2021

e ISSN : 2774-1982

DOI : https://doi.org/10.47687/snppvp.v2i1.168

(2005) bagi sifat fisik tanah, pupuk berperan dalam menyeimbangkan kondisi tanah sehingga terjadi peningkatan porositas, aerase tanah, daya penyediaan air tanah dan mengoptimalkan kelengasan tanah pada atau dibawah titik layu parmenan. Percobaan ini bertujuan untuk mengkaji pengaruh pemberian kompos granul ela sagu dan pupuk fosfor terhadap perbaikan beberapa sifat fisik tanah inceptisol dan pertumbuhan tanaman jagung.

\section{METODE}

Percobaan dilaksanakan pada bulan Mei 2020 di rumah kaca Fakultas Pertanian Universitas Pattimura dan dilanjutkan dengan analisa laboratorium di laboratorium tanah Fakultas Pertanian Universitas Brawijaya Malang dan BALITAN Bogor. Materi yang digunakan adalah tanah inceptisol, pupuk fosfat, kompos granul ela sagu dan benih jagung jagung varietas srikandi kuning. Percobaan dirancang menggunakan rancangan acak kelompok (RAL) berpola faktorial 3 x 3 dengan 3 ulangan. Faktor pertama adalah Kompos Granul Ela Sagu (ES) yang terdiri atas tiga taraf, yaitu KGES 0 (tanpa Kompos Granul ela sagu); $\mathrm{KGES}_{1}\left(100 \mathrm{~g} \mathrm{pot}^{-1}\right)$; dan $\mathrm{KGES}_{2}\left(200 \mathrm{~g} \mathrm{pot}^{-1}\right)$. Faktor kedua adalah pupuk SP-36 (P) yang terdiri atas tiga taraf, yaitu $\mathrm{P}_{0}$ (tanpa pupuk phosphat); $\mathrm{P}_{1}(0.326 \mathrm{~g}$ pot $\left.^{-1}\right)$; dan $\mathrm{P}_{2}\left(0.652 \mathrm{~g} \mathrm{pot}^{-1}\right)$. Perlakuan-perlakuan ini diulang 3 kali sehingga terdapat 27 satuan kombinasi percobaan $(3 \times 3 \times 3)$ yang dibuat dalam dua kelompok yaitu kelompok yang ditanami (27 satuan percobaan) dan kelompok yang tidak ditanami (27 satuan percobaan). Data-data yang diperoleh selama percobaan disusun menggunakan program Microsoft Excel dan dianalisis keragamannya menggunakan program Genstat $12^{\text {th }}$ for windows. Analisis ragam (ANOVA) sesuai dengan rancangan dan pola percobaan yang digunakan yaitu RAK, dan apabila berbeda nyata dilanjutkan dengan uji Duncan Multiple Range Test (DMRT) pada taraf 5\%. Analisis korelasi dan regresi digunakan untuk mengetahui keeratan dan bentuk hubungan antara perlakuan dan variabel yang diamati. Parameter yang diamati untuk komponen tanah adalah berat volume tanah, berat jenis tanah, porositas, pori drainase cepat, pori drainase lambat, pori air tersedia, pori air tidak tersedia dan hasil biji pipilan kering jagung.

\section{HASIL DAN PEMBAHASAN}

\section{Pembuatan dan Kualitas Pupuk Kompos Granule Diperkaya}

Berdasarkan hasil analisis dasar kualitas unsur hara kompos granul ela sagu menunjukkan bahwa $\mathrm{pH}$ kompos cenderung agak basa $\left(\mathrm{pH} \mathrm{H}_{2} \mathrm{O} 7.8\right.$ dan $\mathrm{pH} \mathrm{KCl}$ 7.5). Hal 
Prosiding Seminar Nasional Pembangunan dan Pendidikan Vokasi Pertanian

Politeknik Pembangunan Pertanian Manokwari, 31 Juli 2021

e ISSN : 2774-1982

DOI : https://doi.org/10.47687/snppvp.v2i1.168

ini menunjukkan bahwa aplikasi kompos berbahan baku ela sagu dapat berfungsi untuk meningkatkan $\mathrm{pH}$ tanah dan mengurangi efek merugikan (penurunan $\mathrm{pH}$ tanah) akibat pemberian pupuk anorganik. Kandungan bahan organik dalam kompos ela sagu relatif tinggi yaitu $26.85 \%$. Sedangkan untuk kandungan nutrisinya, konsentrasi unsur hara $\mathrm{N}, \mathrm{P}$, dan $\mathrm{K}$ yang ada dalam kompos berbahan baku ela sagu berturut-turut sebesar 1,56\%, $1,03 \%$ dan $0,69 \%$. dengan kadar air $12-15 \%$. Apabila dibandingkan dengan kandungan hara dari kotoran hewan seperti sapi dan ayam (hasil penelitian Tanah, 1993), kandungan unsur $\mathrm{N}$ dan $\mathrm{P}$, dari kompos berbahan baku ela sagu cenderung lebih tinggi, sedangkan unsur $\mathrm{K}$ masih lebih rendah daripada kotoran ayam, namun lebih tinggi dibandingkan kotoran sapi. Kompos yang diproduksi memiliki C/N ratio 10 yang berarti bahwa pupuk tersebut termasuk kualitas tinggi dan cepat terdekomposisi sehingga lebih cepat dalam penyediaan unsur hara. Pengkayaan unsur hara yang dilakukan melalui penambahan NPK mampu meningkatkan kandungan $\mathrm{N}, \mathrm{P}$ dan $\mathrm{K}$, masing-masing menjadi $\mathrm{N}=2.43 \%, \mathrm{P}=$ $1,02 \%$ dan $\mathrm{K}=0.87 \%$.

\section{Analisa Pendahuluan}

Sebelum perlakuan tanah lnceptisol yang akan digunakan dalam percobaan dianalisa karakteristiknya melalui analisa pendahuluan. Hasil analisa pendahuluan sifatsifat fisik dan kimia baik tanah Inceptisol sebelum percobaan tertera pada Tabel 1.

Tabel 1. Beberapa Sifat Fisik dan Kimia Tanah Inceptisol Sebelum Percobaan

\begin{tabular}{lll}
\hline No. & Sifat fisik tanah (kedalaman 0-20 cm) & Hasil analisis \\
\hline 1 & Tektur : & \\
& - Pasir (\%) & 16 \\
& - Debu (\%) & 40 \\
& - Liat (\%) & 44 \\
\hline 2 & Berat volume tanah $\left(\mathrm{g} \mathrm{cm}^{-3}\right)$ & 1,2 \\
& \\
\hline 3 & Berat jenis tanah $\left(\mathrm{g} \mathrm{cm}^{-3}\right)$ & 2,44 \\
& & \\
\hline 4 & Porositas Tanah $(\%$ volume) & 52,3 \\
& & \\
& Penyebaran Pori & 33,0 \\
& - Pori Drainase cepat $(\%$ volume $)$ & 5,5 \\
& - Pori Drainase lambat $(\%$ volume) & 8,0 \\
& - Pori air tersedia $(\%$ volume $)$ & 8,2 \\
\hline & - Pori air tidak tersedia $(\%$ volume & 0,46 \\
& Kadar air pF $2\left(\mathrm{~cm}^{3} . \mathrm{cm}^{-3}\right)$ & 2 \\
\hline
\end{tabular}


Prosiding Seminar Nasional Pembangunan dan Pendidikan Vokasi Pertanian Politeknik Pembangunan Pertanian Manokwari, 31 Juli 2021

e ISSN : 2774-1982

DOI : https://doi.org/10.47687/snppvp.v2i1.168

Hasil analisa tanah inceptisol menunjukkan bahwa, tanah didominasi oleh fraksi liat (44\%) diikuti oleh fraksi debu (40\%) dan fraksi pasir (16\%) sehingga termasuk dalam kelas tekstur liat. Adanya tekstur liat menyebabkan nilai porositas sedang $(52,3 \%$ volume) dimana didominasi oleh pori drainase cepat $(33,0 \%$ volume $)$ memyusul berturut-turut pori air tidak tersedia $(8,2 \%$ volume), pori air tersedia ( $8.0 \%$ volume) dan pori drainase lambat (5.5\% volume) hal ini disebabkan karena tanah didominasi oleh pori mikro sehingga sebagian air sulit terlindih setelah penambahan air terhenti.

Hasil analisa kompos granul ela sagu menunjukkan bahwa kompos granul ela sagu mempunyai C-organik dan $\mathrm{N}$ total tinggi masing-masing $(30,16 \%)$ dan $(2,43 \%)$. Berdasarkan hasil analisa diharapkan penggunaan kompos granul ela sagu sebagai bahan perlakuan dapat meningkatkan agregasi tanah sehingga berpengaruh pada sifat fisik tanah Inceptisols. Hasil analisa ragam tanah inceptisol terhadap parameter berat volume tanah menunjukkan bahwa perlakuan kompos granul ela sagu berpengaruh nyata menurunkan berat volume tanah, tetapi baik perlakuan pupuk fosfat maupun interaksinya tidak berbeda nyata.

\section{Berat Volume Tanah $\left(\mathrm{g.cm}^{-3}\right)$}

Hasil analisa ragam tanah Inceptisol terhadap parameter berat volume tanah menunjukkan bahwa perlakuan kompos granul ela sagu berpengaruh nyata menurunkan berat volume tanah, tetapi baik perlakuan urea maupun interaksinya tidak berbeda nyata. Pengaruh dosis perlakuan kompos granul ela sagu dan pupuk fosfat terhadap berat volume tanah inceptisol dapat dilihat pada (Tabel 2).

Tabel 2. Pengaruh dosis perlakuan kompos granul ela sagu dan pupuk fosfat terhadap jenis berat volume tanah Inceptisol $\left(\mathrm{g} \mathrm{cm}^{-3}\right)$

\begin{tabular}{ccccc}
\hline Kompos granul ela sagu & \multicolumn{3}{c}{ Fosfat $\left(\mathrm{kg} . \mathrm{P} . \mathrm{ha}^{-1}\right)$} & Rerata \\
$\left(\right.$ ton ha $\left.{ }^{-1}\right)$ & $\mathrm{P} 0$ & $\mathrm{P} 1$ & $\mathrm{P} 2$ & \\
\hline KGES 0 $\left(0\right.$ t.ha $\left.^{-1}\right)$ & 1,2 & 1,1 & 1,1 & $1,2 \mathrm{a}$ \\
KGES 1 $\left(20 \mathrm{t} \mathrm{tha}^{-1}\right)$ & 0,8 & 0,9 & 0,8 & $0,98 \mathrm{~b}$ \\
KGES 2 $\left(40\right.$ t.ha $\left.^{-1}\right)$ & 0,9 & 0,8 & 0,9 & $0,93 \mathrm{~b}$ \\
\hline Rerata & $0,97 \mathrm{c}$ & $0,93 \mathrm{c}$ & $0,97 \mathrm{c}$ & \\
\hline
\end{tabular}

Keterangan : Angka yang diikuti oleh huruf yang sama menurut arah baris maupun arah kolom menunjukkan tidak ada beda nyataberdasarkan uji jarak berganda Duncan pada jenjang nyata $5 \%$. Tanda (-) menunjukkan tidak ada interaksi

Berdasarkan Tabel 2 tampak bahwa pemberian kompos granul ela sagu dengan dosis 0 t.ha $^{-1}$, ditingkatkan ke 20 t.ha $^{-1}$ berbeda nyata menurunkan berat volume tanah Inceptisol tetapi bila dosis ela sagu ditingkatkan menjadi 40 t.ha $^{-1}$ maka akan nyata, tetapi dosis 20 t.ha ${ }^{-1}$ dibandingkan dengan dosis 40 t.ha $^{-1}$ tidak berbeda nyata menurunkan berat 
Prosiding Seminar Nasional Pembangunan dan Pendidikan Vokasi Pertanian

Politeknik Pembangunan Pertanian Manokwari, 31 Juli 2021

e ISSN : 2774-1982

DOI : https://doi.org/10.47687/snppvp.v2i1.168

volume tanah inceptisol. Turunnya berat volume tanah inceptisol disebabkan karena keberadaan bahan organik pada kompos granul ela sagu yang berperan dalam mengikat pertikel-pertikel tanah sehingga membentuk pola tertentu. Hal ini sejalan dengan pendapat Baver et al. (1972) bahwa, senyawa organik kompleks hasil proses dekomposisi bahan organik dapat berfungsi sebagai semen dalam proses granulasi. Ditambahkan juga oleh Hillel (1996) bahwa, bahan organik memiliki berat isi maupun berat jenis yang rendah sehingga makin tinggi pemberian bahan organik ke tanah maka berat volume tanah akan menurun. Terbukti penambahan bahan organik (pupuk kandang) akan meningkatkan pori total tanah dan akan menurunkan berat volume tanah (Wiskandar, 2002).

\section{Berat jenis butiran tanah $\left(\mathrm{g} \mathrm{cm}^{-3}\right)$}

Hasil analisis ragam terhadap parameter berat jenis butiran tanah menunjukkan bahwa pada tanah inceptisol baik perlakuan kompos granul ela sagu, perlakuan fosfor maupun interaksi keduanya macam berbeda nyata meningkatkan jenis butiran tanah. Pengaruh dosis perlakuan kompos granul ela sagu dan pupuk fosfat terhadap berat jenis butiran tanah Inceptisol dapat dilihat pada (Tabel 3).

Tabel 3. Pengaruh dosis perlakuan kompos granul ela sagu dan pupuk fosfat terhadap jenis butiran tanah Inceptisol $\left(\mathrm{g} \mathrm{cm}^{-3}\right)$

\begin{tabular}{|c|c|c|c|c|}
\hline \multirow{2}{*}{$\begin{array}{c}\text { Kompos granul ela sagu } \\
\left(\text { ton.ha } \text { ha }^{-1}\right)\end{array}$} & \multicolumn{3}{|c|}{ Fosfat $\left(\mathrm{kg} \mathrm{P} . \mathrm{Ha}^{-1}\right)$} & \multirow[t]{2}{*}{ Rerata } \\
\hline & P0 & P1 & $\mathrm{P} 2$ & \\
\hline \multirow[t]{2}{*}{ KGES $0\left(0\right.$ t.ha $\left.^{-1}\right)$} & $2,1 \mathrm{a}$ & $2,3 \mathrm{a}$ & $2,2 \mathrm{a}$ & 2,2 \\
\hline & A & B & A & \\
\hline \multirow[t]{2}{*}{ KGES $1\left(20\right.$ t.ha $\left.^{-1}\right)$} & $2,2 \mathrm{~b}$ & $2,2 \mathrm{a}$ & $2,5 \mathrm{~b}$ & 2,3 \\
\hline & A & A & B & \\
\hline \multirow[t]{2}{*}{ KGES $2\left(40\right.$ t.ha $\left.^{-1}\right)$} & $2,2 \mathrm{~b}$ & $2,1 \mathrm{a}$ & $2,2 \mathrm{a}$ & 2,3 \\
\hline & A & $\mathrm{B}$ & $\mathrm{AB}$ & \\
\hline Rerata & 2,3 & 2,2 & 2,3 & \\
\hline
\end{tabular}

Keterangan : Angka yang diikuti oleh huruf yang sama menurut arah baris maupun arah kolom menunjukkan tidak ada beda nyataberdasarkan uji jarak berganda Duncan pada taraf nyata $5 \%$. Tanda (-) menunjukkan tidak ada interaksi

Berdasarkan Tabel 3 terlihat bahwa penambahan kompos granul ela sagu dari dosis $0 \mathrm{t}$. ha ${ }^{-1-1}$ dengan fosfat $0 \mathrm{~kg}$ ha ${ }^{-1}$ bila dosis ditingkatkan menjadi $120 \mathrm{~kg} \mathrm{P}^{-1}$ maka akan berbeda nyata tetapi bila dosis fosfat ditingkatkan menjadi $240 \mathrm{~kg} \mathrm{P}^{\text {ha }}{ }^{-1}$ tidak berpengaruh nyata terhadap dosis fosfat $0 \mathrm{~kg} \mathrm{P} \mathrm{ha}^{-1}$ tetapi berpengaruh nyata terhadap dosis fosfat $120 \mathrm{~kg} \mathrm{P} \mathrm{ha-1}$. Pemberian dosis kompos granul ela sagu 20 t.ha $^{-1}$ dengan fosfat 0 t.ha $^{-1}$ tidak berbeda nyata meningkatkan berat jenis butiran tanah terhadap dosis pupuk fosfat $120 \mathrm{~kg} \mathrm{P} \mathrm{ha}^{-1}$ tetapi bila dosis pupuk fosfat ditingkatkan menjadi $240 \mathrm{~kg} \mathrm{P}$ 
Prosiding Seminar Nasional Pembangunan dan Pendidikan Vokasi Pertanian

Politeknik Pembangunan Pertanian Manokwari, 31 Juli 2021

e ISSN : 2774-1982

DOI : https://doi.org/10.47687/snppvp.v2i1.168

ha ${ }^{-1}$ akan berbeda nyata. Pemberian dosis kompos granul ela sagu $40 \mathrm{~g} \mathrm{pot}^{-1}$ dengan fosfat $0 \mathrm{~g} \mathrm{pot}^{-1}$ berbeda nyata meningkatkan berat jenis butiran terhadap dosis pupuk fosfat $120 \mathrm{~kg} \mathrm{P}^{-1}$ tetapi bila dosis pupuk fosfat ditingkatkan menjadi $240 \mathrm{~kg} \mathrm{P}^{-1}$ tidak berbeda nyata baik terhadap dosis pupuk fosfat $0 \mathrm{~g} \mathrm{pot}^{-1}$ maupun terhadap dosis pupuk fosfat $240 \mathrm{~kg} \mathrm{P} \mathrm{ha}^{-1}$. Hal ini dapat dijelaskan bahwa berat jenis butiran tanah ditentukan oleh partikel padatan tanah yang cenderung tetap untuk tiap jenis tanah, berat ringannya partikel padatan tanah ditentukan oleh tingkat pelapukan yang memerlukan waktu yang cukup lama, tetapi bahan organik dalam bentuk humus dapat meningkatkan jenis butiran tanah. Berat jenis butiran tanah relatif tetap, akan berubah dengan penambahan humus, pelapukan dan hilangnya mineral-mineral penyusun tanah itupun memerlukan waktu yang cukup lama.

\section{Porositas tanah $(\%)$}

Hasil analisis ragam terhadap parameter porositas tanah menunjukkan bahwa perlakuan kompos granul ela sagu, berbeda nyata meningkatkan porositas tanah, tetapi perlakuan fosfat dan interaksi keduanya tidak berbeda nyata. Pengaruh dosis perlakuan kompos granul ela sagu dan pupuk fosfat terhadap porositas tanah inceptisol dapat dilihat pada (Tabel 4).

Tabel 4. Pengaruh dosis perlakuan kompos granul ela sagu dan pupuk fosfat terhadap porositas tanah Inceptisol (\%)

\begin{tabular}{|c|c|c|c|c|}
\hline \multirow{2}{*}{$\begin{array}{l}\text { Kompos granul ela sagu } \\
\text { (ton. } \text { ha }^{-1} \text { ) }\end{array}$} & \multicolumn{3}{|c|}{ Fosfat $\left(\mathrm{kg} \mathrm{P} \mathrm{ha}^{-1}\right)$} & \multirow[t]{2}{*}{ Rerata } \\
\hline & $\mathrm{P} 0$ & $\mathrm{P} 1$ & $\mathrm{P} 2$ & \\
\hline KGES $0\left(0\right.$ t.ha $\left.{ }^{-1}\right)$ & 4,4 & 4,4 & 4,7 & $4,5 \mathrm{a}$ \\
\hline KGES $1\left(20\right.$ t.ha $\left.^{-1}\right)$ & 6,7 & 6,7 & 7,3 & $6,9 \mathrm{~b}$ \\
\hline KGES $2\left(40\right.$ t.ha $\left.^{-1}\right)$ & 8,3 & 8,3 & 7,0 & $7,8 \mathrm{~b}$ \\
\hline Rerata & $6,4 \mathrm{c}$ & $6,43 \mathrm{c}$ & $6,3 \mathrm{c}$ & \\
\hline
\end{tabular}

Keterangan : Angka yang diikuti oleh huruf yang sama menurut arah baris maupun arah kolom menunjukkan tidak ada beda nyataberdasarkan uji jarak berganda Duncan pada taraf nyata $5 \%$. Tanda (-) menunjukkan tidak ada interaksi

Berdasarkan Tabel 4 tampak bahwa kombinasi pemberian kompos granul ela sagu dari 0 t.ha ${ }^{-1}$ menjadi 20 tha $^{-1}$ berbeda nyata mempengaruhi peningkatan porositas tanah sedangkan bila dosis ini ditingkatkan lagi menjadi 40 t.ha $^{-1}$ akan berbeda nyata terhadap dosis pemberian $0 \mathrm{~g} \mathrm{pot}^{-1}$ tetapi tidak berbeda nyata terhadap dosis pemberian 20 t.ha $^{-1}$. Peningkatan tersebut dapat terjadi karena kemampuan bahan organik dalam memacu terbentuknya agregat-agregat tanah dapat dilihat pada penurunan berat volume tanah, hal ini sesuai pendapat Gregorich et al. (2002) bahwa bahan organik membentuk senyawasenyawa mycelia, lendir dan lumpur akibat aktivitas mikroorganisme dimana berfungsi 
Prosiding Seminar Nasional Pembangunan dan Pendidikan Vokasi Pertanian

Politeknik Pembangunan Pertanian Manokwari, 31 Juli 2021

e ISSN : 2774-1982

DOI : https://doi.org/10.47687/snppvp.v2i1.168

sebagai perekat butiran-butiran tanah menjadi agregat-agregat kemudian menjadi poripori yang dapat menyimpan air dan mengalirkan udara. Pengaruh bahan organik terhadap tanah dan akibatnya terhadap tumbuhan adalah sebagai granulator, yaitu memperbaiki struktur tanah, sumber unsur hara $\mathrm{N}, \mathrm{P}, \mathrm{K}, \mathrm{Ca}, \mathrm{Mg}, \mathrm{S}$, unsur mikro, menambah kemampuan tanah untuk menahan air serta merupakan sumber energi bagi mikroorganisme (Hardjowigeno, 2003).

\section{Pori drainase cepat (Ø 30-296 $\mu \mathrm{m}$ )}

Hasil analisis ragam terhadap parameter pori drainase cepat menunjukkan bahwa baik perlakuan kompos granul ela sagu dan perlakuan fosfat berbeda nyata menurunkan pori drainase cepat sedangkan interaksi keduanya tidak berbeda nyata. Pengaruh dosis perlakuan kompos ela sagu dan pupuk fosfat terhadap pori drainase cepat tanah Inceptisol dapat dilihat pada Tabel 5.

Tabel 5. Pengaruh dosis perlakuan kompos granul ela sagu dan pupuk fosfat terhadap pori drainase cepat tanah Inceptisol (\%)

\begin{tabular}{crrrr}
\hline Kompos granul ela sagu & \multicolumn{3}{c}{ Fosfat $\left(\mathrm{kg} \mathrm{P} \mathrm{ha}^{-1}\right)$} & Rerata \\
(ton ha $\left.\mathrm{h}^{-1}\right)$ & $\mathrm{P} 0$ & $\mathrm{P} 1$ & $\mathrm{P} 2$ & \\
\hline KGES 0 $\left(0\right.$ t.ha $\left.^{-1}\right)$ & 33,1 & 32,2 & 29,2 & $31,50 \mathrm{a}$ \\
KGES 1 $\left(20 \mathrm{t.ha}^{-1}\right)$ & 27,6 & 27,3 & 27,01 & $27,07 \mathrm{~b}$ \\
KGES 2 $\left(40 \mathrm{tha}^{-1}\right)$ & 32,6 & 27,11 & 23,61 & $28,61 \mathrm{c}$ \\
\hline Rerata & $31,1 \mathrm{a}$ & $29,53 \mathrm{a}$ & $26,60 \mathrm{~b}$ & \\
\hline
\end{tabular}

Keterangan : Angka yang diikuti oleh huruf yang sama menurut arah baris maupun arah kolom menunjukkan tidak ada beda nyataberdasarkan uji jarak berganda Duncan pada taraf nyata $5 \%$. Tanda (-) menunjukkan tidak ada interaksi

Dari Tabel 5 tampak bahwa peningkatan pemberian kompos granul ela sagu dari dosis 0 t.ha ${ }^{-1}$ menjadi 20 t.ha $^{-1}$ akan berbeda nyata menurunkan pori drainase cepat tanah Inceptisol dan bila dosis ini ditingkatkan menjadi 40 t.ha $^{-1}$ akan berbeda nyata baik terhadap pemberian dosis 0 t.ha ${ }^{-1}$ maupun 20 t.ha $^{-1}$ demikian juga peningkatan pemberian dosis fosfat dari 0 tha ${ }^{-1}$ menjadi 20 tha $^{-1}$ tidak berbeda nyata menurunkan pori drainase cepat tanah Inceptisol tetapi bila dosis ini ditingkatkan menjadi 40 t.ha $^{-1}$ akan berbeda nyata terhadap dosis pemberian fosfat baik $0 \mathrm{~kg} \mathrm{P}^{-1}$ maupun $240 \mathrm{~kg} \mathrm{P}^{-1}$. Penurunan pori drainase cepat menunjukkan berkurangnya pori-pori tanah yang berdiameter 30 sampai $296 \mu \mathrm{m}$ akibat agregasi tanah. Adanya penurunan pori drainase cepat berarti adanya oksigen, nitrogen dan uap air yang dibutuhkan oleh akar untuk bernafas. Peningkatan oksigen, karbondioksida, nitrogen dan uap air bersamaan dengan meningkatnya lengas tanah atau porositas (Kertonegoro, 2001). Pemberian bahan organik memungkinkan pembentukkan agregat tanah, yang selanjutnya akan memperbaiki 
Prosiding Seminar Nasional Pembangunan dan Pendidikan Vokasi Pertanian

Politeknik Pembangunan Pertanian Manokwari, 31 Juli 2021

e ISSN : 2774-1982

DOI : https://doi.org/10.47687/snppvp.v2i1.168

permeabilitas dan peredaran udara tanah, akar tanaman mudah menembus lebih dalam dan luas sehingga tanaman kokoh dan lebih mampu menyerap hara tanaman (Winarso, 2005).

\section{Pori drainase lambat $(\varnothing 8,6 \mu \mathrm{m}$ sampai $30 \mu \mathrm{m})$}

Hasil analisis ragam terhadap parameter pori drainase lambat menunjukkan bahwa perlakuan kompos granul ela sagu berpengaruh nyata meningkatkan pori drainase lambat sedangkan pupuk fosfat dan interaksi keduanya tidak berbeda nyata. Pengaruh dosis perlakuan kompos granul ela sagu dan pupuk fosfat terhadap pori drainase lambat tanah Inceptisol dapat dilihat pada Tabel 6.

Tabel 6. Pengaruh dosis perlakuan kompos granul ela sagu dan pupuk fosfat terhadap pori drainase lambat tanah Inceptisol (\%)

\begin{tabular}{ccccc}
\hline Kompos granul ela sagu & \multicolumn{3}{c}{ Fosfat $\left(\mathrm{kg} \mathrm{P} \mathrm{ha}^{-1}\right)$} & Rerata \\
(ton. ha $\left.)^{-1}\right)$ & P0 & P1 & P2 & \\
\hline KGES 0 $\left(0\right.$ t.ha $\left.^{-1}\right)$ & 5,5 & 6,2 & 6,2 & $5,97 \mathrm{a}$ \\
KGES 1 $\left(20\right.$ t.ha $\left.^{-1}\right)$ & 11,7 & 7,6 & 7,4 & $8,90 \mathrm{~b}$ \\
KGES 2 $\left(40\right.$ t.ha $\left.^{-1}\right)$ & 7,31 & 8,51 & 8,5 & $8,11 \mathrm{~b}$ \\
\hline Rerata & $8,17 \mathrm{c}$ & $7,07 \mathrm{c}$ & $7,37 \mathrm{c}$ & \\
\hline
\end{tabular}

Keterangan : Angka yang diikuti oleh huruf yang sama menurut arah baris maupun arah kolom menunjukkan tidak ada beda nyataberdasarkan uji jarak berganda Duncan pada taraf nyata $5 \%$. Tanda (-) menunjukkan tidak ada interaksi

Berdasarkan tabel 6 tampak bahwa peningkatan pemberian kompos granul ela sagu dosis 0 t.ha $^{-1}$ menjadi 20 t.ha ${ }^{-1}$ tidak berbeda nyata meningkatkan pori drainase lambat tanah Inceptisol, tetapi bila dosis kompos ela sagu ditingkatkan menjadi 40 t.ha $^{-1}$ akan berbeda nyata terhadap dosis 0 t.ha $^{-1}$ tetapi tidak berbeda nyata dengan dosis pemberian 20 t.ha ${ }^{-1}$. Peningkatan pori drainase lambat menandakan terbentuknya pori dengan garis tengah $8,6 \mu \mathrm{m}$ sampai $30 \mu \mathrm{m}$ akibat membaiknya struktur tanah, hal ini ditandai dengan menurunnya berat volume tanah (Tabel 2) dan meningkatnya porositas (Tabel 4) secara nyata. Menurut Widianto et al., (2003), sifat-sifat fisik tanah (lapisan atas) dalam hal ini porositas tanah sangat penting untuk menunjang pertumbuhan tanaman. Pori tanah menyediakan ruang yang mewadahi berbagai proses dan kegiatan kimia, fisik dan biologi yakni organisme makro dan mikro termasuk perakaran tanaman dan pepohonan.

\section{Pori air tersedia (Ø 0,2 -8,6 $\mu \mathrm{m})$}

Hasil analisis ragam terhadap parameter pori air tersedia menunjukkan bahwa pada tanah Inceptisol baik perlakuan kompos granul ela sagu maupun pupuk fosfat berpengaruh nyata meningkatkan pori air tersedia sedangkan interaksi dari kedua macam 
Prosiding Seminar Nasional Pembangunan dan Pendidikan Vokasi Pertanian

Politeknik Pembangunan Pertanian Manokwari, 31 Juli 2021

e ISSN : 2774-1982

DOI : https://doi.org/10.47687/snppvp.v2i1.168

perlakuan tidak berbeda nyata. Pengaruh dosis perlakuan kompos granul ela sagu dan pupuk fosfat terhadap pori air tersedia tanah Inceptsol dapat dilihat pada (Tabel 7).

Tabel 7. Pengaruh dosis perlakuan kompos granul ela sagu dan pupuk fosfat terhadap pori air tersedia tanah Inceptisol (\%)

\begin{tabular}{ccccc}
\hline $\begin{array}{c}\text { Kompos granul ela sagu } \\
\left.\text { (ton ha } \mathrm{h}^{-1}\right)\end{array}$ & P0 & Posfat $\left(\mathrm{kg} \mathrm{P} \mathrm{ha}^{-1}\right)$ & Rerata \\
\hline KGES 0 $\left(0\right.$ t.ha $\left.^{-1}\right)$ & 8,03 & 8,4 & 8,6 & $8,36, \mathrm{a}$ \\
KGES 1 $\left(20\right.$ t.ha $\left.^{-1}\right)$ & 9,1 & 9,3 & 9,8 & $9,42 \mathrm{~b}$ \\
KGES 2 $\left(40\right.$ t.ha $\left.^{-1}\right)$ & 10,87 & 11,6 & 11,9 & $11,46 \mathrm{~b}$ \\
\hline Rerata & $9,33 \mathrm{a}$ & $9,77 \mathrm{ab}$ & $10,15 \mathrm{c}$ & \\
\hline
\end{tabular}

Keterangan : Angka yang diikuti oleh huruf yang sama menurut arah baris maupun arah kolom menunjukkan tidak ada beda nyataberdasarkan uji jarak berganda Duncan pada jenjang nyata $5 \%$. Tanda (-) menunjukkan tidak ada interaksi

Dari Tabel 7, tampak bahwa pada peningkatan pemberian kompos granul ela sagu dari dosis 0 t.ha ${ }^{1}$ menjadi 20 t.ha $^{-1}$ akan berbeda nyata meningkatkan pori air tersedia tanah Inceptisol dan bila dosis ini ditingkatkan menjadi 40 t.ha ${ }^{-1}$ akan berbeda nyata baik terhadap pemberian 0 t.ha- ${ }^{-1}$ maupun 20 t.ha $^{-1}$ sedangkan pada peningkatan pemberian dosis fosfat dari $0 \mathrm{~kg} \mathrm{P}$ ha menjadi $120 \mathrm{~kg} \mathrm{P}^{-1}$ tidak berbeda nyata meningkatkan pori air tersedia tanah Inceptisol tetapi bila dosis ini ditingkatkan menjadi $240 \mathrm{~kg} \mathrm{P}^{-1}$ akan berbeda nyata terhadap dosis pemberian fosfat baik $0 \mathrm{~kg} \mathrm{P}^{-1}$ tetapi tidak berbeda nyata terhadap dosis pemberian $120 \mathrm{~kg} \mathrm{P} \mathrm{ha}^{-1}$.

Peningkatan pori air tersedia disebabkan karena C-organik yang tinggi pada kompos granul ela sagu (Tabel 1) mengisi ruang antar makroagregat, domain dari kristal lempung, fraksi debu dan pasir sehingga terbentuk pori-pori mikro, disamping peranan bahan organik dalam proses agregasi tanah. Meningkatnya pori air tersedia menandakan bahwa telah terbentuk pori dengan garis tengah $0,2 \mu \mathrm{m}$ sampai pori dengan garis tengah $8,6 \mu \mathrm{m}$.

\section{Pori air tidak tersedia $(\varnothing<0,2 \mu \mathrm{m})$}

Pori air tidak tersedia adalah pori tanah dengan garis tengah lebih kecil dari $0,2 \mu \mathrm{m}$ yang setara dengan kadar air pada $\mathrm{pF} 4,2$. Presentasi pori air tidak tersedia merupakan nilai kadar lengas pada $\mathrm{pF}$ 4,2 dikali berat volume tanah. Hasil sidik ragam terhadap parameter pori air tidak tersedia menunjukkan bahwa pada tanah Inceptisol perlakuan kompos granul ela sagu berpengaruh nyata meningkatkan pori air tidak tersedia sedangkan baik perlakuan pupuk urea maupun interaksi dari kedua macam perlakuan tidak berbeda nyata. Pengaruh dosis perlakuan kompos granul ela sagu dan pupuk fosfat terhadap pori air tidak tersedia tanah Inceptisol dapat dilihat pada Tabel 8. 
Prosiding Seminar Nasional Pembangunan dan Pendidikan Vokasi Pertanian

Politeknik Pembangunan Pertanian Manokwari, 31 Juli 2021

e ISSN : 2774-1982

DOI : https://doi.org/10.47687/snppvp.v2i1.168

Tabel 8. Pengaruh dosis perlakuan kompos granul ela sagu dan pupuk fosfat terhadap pori air tidak tersedia tanah Inceptisol (\%)

\begin{tabular}{|c|c|c|c|c|}
\hline \multirow{2}{*}{$\begin{array}{l}\text { Kompos granul ela sagu } \\
\left.\text { (ton } \mathrm{ha}^{-1}\right)\end{array}$} & \multicolumn{3}{|c|}{ fosfat $\left(\mathrm{kg} \mathrm{P} \mathrm{ha}^{-1}\right)$} & \multirow[t]{2}{*}{ Rerata } \\
\hline & $\mathrm{P} 0$ & P1 & $\mathrm{P} 2$ & \\
\hline KGES $0\left(0\right.$ t.ha $\left.^{-1}\right)$ & 8,03 & 8,4 & 8,6 & $8,34 \mathrm{a}$ \\
\hline KGES $1\left(20\right.$ t.ha $\left.^{-1}\right)$ & 9,1 & 9,3 & 9,8 & $9,41 \mathrm{~b}$ \\
\hline KGES $2\left(40\right.$ t.ha $\left.^{-1}\right)$ & 10,87 & 11,6 & 11,9 & $11,45 \mathrm{c}$ \\
\hline Rerata & $9,33 \mathrm{a}$ & $9,15 \mathrm{ab}$ & $10,15 \mathrm{~b}$ & \\
\hline
\end{tabular}

Keterangan : Angka yang diikuti oleh huruf yang sama menurut arah baris maupun arah kolom menunjukkan tidak ada beda nyataberdasarkan uji jarak berganda Duncan pada taraf nyata $5 \%$. Tanda (-) menunjukkan tidak ada interaksi

Dari Tabel 8 tampak bahwa peningkatan pemberian kompos granul ela sagu dari dosis 0 t.ha ${ }^{-1}$ menjadi 20 t.ha $^{-1}$ akan berbeda nyata meningkatkan pori air tidak tersedia tanah Inceptisol dan bila dosis ini ditingkatkan menjadi 40 t.ha ${ }^{-1}$ akan berbeda nyata baik terhadap dosis pemberian 0 t.ha ${ }^{-1}$ maupun 20 t.ha $^{-1}$ sedangkan peningkatan pemberian fosfat dari dosis $0 \mathrm{~kg} \mathrm{P}$ ha ${ }^{-1}$ menjadi $120 \mathrm{~kg} \mathrm{P}^{-1}$ tidak berbeda nyata meningkatkan pori air tidak tersedia tanah Inceptisol dan bila dosis ini ditingkatkan menjadi $240 \mathrm{~kg} P$ $\mathrm{ha}^{-1}$ akan berbeda nyata terhadap dosis pemberian $0 \mathrm{~kg} \mathrm{P}^{-1}$ tetapi tidak berbeda nyata terhadap dosis pemberian $120 \mathrm{~kg} \mathrm{P} \mathrm{ha-1}$. Peningkatan ini menunjukkan bahwa bahan organik kompos granul ela sagu berperan dalam pembentukan agregat yang menghasilkan agregat-agregat mikro. Pemberian bahan organik memungkinkan pembentukkan agregat tanah, yang selanjutnya akan memperbaiki permeabilitas dan peredaran udara tanah, akar tanaman mudah menembus lebih dalam dan luas sehingga tanaman kokoh dan lebih mampu menyerap hara tanaman (Winarso, 2005).

\section{Hasil Berat kering Biji Pipilan Jagung (ton ha' ${ }^{-1}$ )}

Hasil Percobaan lapangan menunjukkan bahwa secara mandiri baik kompos granul ela sagu, pupuk fosfat, maupun interaksi antara kompos granul ela sagu dengan pupuk fosfat berpengaruh nyata terhadap berat pipilan kering jagung dapat dilihat pada Tabel 9. 
Prosiding Seminar Nasional Pembangunan dan Pendidikan Vokasi Pertanian

Politeknik Pembangunan Pertanian Manokwari, 31 Juli 2021

e ISSN : 2774-1982

DOI : https://doi.org/10.47687/snppvp.v2i1.168

Tabel 9. Hasil Pipilan Kering Jagung Bila Diberi kompos granul Ela Sagu Dengan Pupuk Fosfat Pada Tanah Inceptisol

\begin{tabular}{|c|c|c|c|}
\hline \multirow{2}{*}{$\begin{array}{l}\text { Bokas kompos granul Ela } \\
\text { Sagsasagu (KGES) }\end{array}$} & \multicolumn{3}{|c|}{ Pupuk Fosfat (P) } \\
\hline & Po $\left(0 \mathrm{~kg} \mathrm{ha}^{-1}\right)$ & P1(120 kg ha-1) & $\mathrm{P}_{2}\left(240 \mathrm{~kg} \mathrm{ha}^{-1}\right)$ \\
\hline & & $(\%) \ldots \ldots \ldots \ldots \ldots$ & \\
\hline \multirow[t]{2}{*}{ KGESo $\left(0\right.$ ton $\left.\mathrm{ha}^{-1}\right)$} & $0,94 \mathrm{a}$ & $2,13 \mathrm{a}$ & $3,41 \mathrm{a}$ \\
\hline & A & B & $\mathrm{C}$ \\
\hline \multirow[t]{2}{*}{$\mathrm{KGES}_{1}(20$ ton ha-1 $)$} & $2,95 \mathrm{~b}$ & $4,68 \mathrm{~b}$ & $6,82 \mathrm{~b}$ \\
\hline & A & B & $\mathrm{C}$ \\
\hline \multirow[t]{2}{*}{$\mathrm{KGES}_{2}\left(40\right.$ ton $\left.\mathrm{ha}^{-1}\right)$} & $3,08 \mathrm{~b}$ & $5,74 \mathrm{c}$ & $7,85 \mathrm{c}$ \\
\hline & A & B & $\mathrm{C}$ \\
\hline
\end{tabular}

Keterangan : Angka-angka yang ditandai denganhuruf yang berbeda ke arah setiap kolom (huruf kecil) dan kea rah baris (huruf besar) adalah nyata menurut uji BNT $5 \%$

Pada Tabel 9 terlihat bahwa pemberian kompos granul ela sagu bersama-sama dengan pupuk fosfat dapat meningkatkan hasil (berat pipilan kering) jagung lebih tinggi dari perlakuan tanpa pupuk fosfat. Perlakuan tanpa pupuk SP-36 $\left(0 \mathrm{~kg} \mathrm{ha}^{-1}\right)$ bila diberi kompos granul ela sagu baik perlakuan 20 ton ha- ${ }^{-1}$ maupun 40 ton $\mathrm{ha}^{-1}$ berbeda nyata dalam meningkatkan hasil berat pipilan kering jagung dibandingkan dengan tanpa diberi kompos granul ela sagu, sedangkan pemberian kompos granul ela sagu 20 ton ha ${ }^{-1}$ tidak berbeda dengan kompos granul ela sagu 40 ton $\mathrm{ha}^{-1}$, walaupun ada peningkatan. Perlakuan pupuk SP-36 baik $120 \mathrm{~kg} \mathrm{P} \mathrm{ha}^{-1}$ dan $240 \mathrm{~kg} \mathrm{P}^{-1}$ tanpa perlakuan kompos granul ela sagu maupun bila diberi kompos granul ela sagu 20 ton ha ${ }^{-1}$ dan 40 ton ha-1 berbeda nyata dalam menaikkan hasil pipilan kering jagung. Pemberian pupuk SP-36 masing-masing dosis 120 dan $240 \mathrm{~kg} \mathrm{ha}^{-1}$ tanpa diberi kompos granul ela sagu dapat menaikkan hasil pipilan kering jagung masing-masing sebesar 1,19 dan 2,67 ton ha $^{-1}$, demikian juga bila diberi kompos granul ela sagu 20 ton ha-1 akan menaikkan hasil pipilan kering jagung sebesar 1,73 dan 3,87 ton ha ${ }^{-1}$ dan bila diberi kompos granul ela sagu 80 ton ha $^{-1}$ dapat menaikkan hasil pipilan kering jagung sebesar 2,66 dan 4,77 ton ha $^{-1}$.

Peningkatan hasil berat kering pipilan jagung disebabkan karena faktor tanah sebagai penghambat pertumbuhan akar tanaman, maka adanya perubahan struktur tanah yang ditandai menurunnya berat volume, meningkatnya porositas, pori aerase dan pori penyimpanan air sehingga dengan bertambahnya dosis pemberian secara langsung berpengaruh bagi pertumbuhan dan perkembangan tanaman. Pemberian bahan organik memungkinkan pembentukkan agregat tanah, yang selanjutnya akan memperbaiki permeabilitas dan peredaran udara tanah, akar tanaman mudah menembus lebih dalam 
Prosiding Seminar Nasional Pembangunan dan Pendidikan Vokasi Pertanian

Politeknik Pembangunan Pertanian Manokwari, 31 Juli 2021

e ISSN : 2774-1982

DOI : https://doi.org/10.47687/snppvp.v2i1.168

dan luas sehingga tanaman kokoh dan lebih mampu menyerap hara tanaman (Winarso, 2005). Bahan organik berfungsi baik memperbaiki struktur tanah hal ini sejalan dengan Hohnke (1989) yang mengemukakan bahwa fungsi bahan organik dalam tanah yaitu selain sumber makanan dan energi bagi mikroorganisme (Hairiah et al., 2000; Hardjowigeno 2003) juga membantu dalam menyediakan hara bagi tanaman melalui perombakan dirinya sendiri dan melalui kapasitas tukar humus dan juga menyediakan zatzat yang dibutuhkan agregasi partikel tanah. Komponen organik seperti asam humat dan asam fulvat dalam hal ini berperan sebagai sedimentasi partikel tanah dengan membentuk kompleks tanah-logam-humus (Stevenson, 1982). Pengaruh bahan organik terhadap tanah dan akibatnya terhadap tumbuhan adalah sebagai granulator, yaitu memperbaiki struktur tanah, sumber unsur hara $\mathrm{N}, \mathrm{P}, \mathrm{K}, \mathrm{Ca}, \mathrm{Mg}, \mathrm{S}$, unsur mikro, menambah kemampuan tanah untuk menahan air serta merupakan sumber energi bagi mikroorganisme (Hardjowigeno, 2003). Bahan organik tanah juga memberikan manfaat biologi melalui penyediaan energi bagi berlangsungnya aktivitas mikroorganisme di dalam tanah (Hairiah et al., 2000). Menurut Widianto et al. (2003), sifat-sifat fisik tanah (lapisan atas) dalam hal ini porositas tanah sangat penting untuk menunjang pertumbuhan tanaman. Pori tanah menyediakan ruang yang mewadahi berbagai proses dan kegiatan kimia, fisik dan biologi yakni organisme makro dan mikro termasuk perakaran tanaman dan pepohonan. Pengaruh bahan organik terhadap tanah dan akibatnya terhadap tumbuhan adalah sebagai granulator, yaitu memperbaiki struktur tanah, sumber unsur hara $\mathrm{N}, \mathrm{P}, \mathrm{K}, \mathrm{Ca}, \mathrm{Mg}, \mathrm{S}$, unsur mikro, menambah kemampuan tanah untuk menahan air serta merupakan sumber energi bagi mikroorganisme (Hardjowigeno, 2003). Bahan organik tanah juga memberikan manfaat biologi melalui penyediaan energi bagi berlangsungnya aktivitas mikroorganisme di dalam tanah (Hairiah et al., 2000). Proses kimia dan biologi dalam rhizosfer tidak hanya menentukan mobilisasi dan akuisisi nutrisi tanah serta dinamika mikroba, tetapi juga mengontrol efisiensi penggunaan nutrisi tanaman, sehingga sangat mempengaruhi produktivitas tanaman (Hinsinger et al., 2009; Richardson et al., 2009; Wissuwa et al., 2009; Zhang et al., 2010). Menurut Widianto et al. (2004), sifat-sifat fisik tanah (lapisan atas) dalam hal ini porositas tanah sangat penting untuk menunjang pertumbuhan tanaman. Pori tanah menyediakan ruang yang mewadahi berbagai proses dan kegiatan kimia, fisik dan biologi yakni organisme makro dan mikro termasuk perakaran tanaman dan pepohonan. 
Prosiding Seminar Nasional Pembangunan dan Pendidikan Vokasi Pertanian

Politeknik Pembangunan Pertanian Manokwari, 31 Juli 2021

e ISSN : 2774-1982

DOI : https://doi.org/10.47687/snppvp.v2i1.168

\section{KESIMPULAN DAN SARAN}

Berdasarkan hasil penelitian lapangan dapat disimpulkan sebagai berikut: 1) Pemberian kompos granul ela sagu berpengaruh nyata terhadap berat volume tanah, jenis butiran tanah, porisitas, pori drainase cepat, pori drainase lambat, pori air tersedia, pori air tidak tersedia dan hasil berat kering pipilan jagung; 2) Pemberian fosfat berpengaruh nyata terhadap jenis butiran tanah, pori drainase cepat, pori air tersedia dan pori air tidak tersedia, porositas, tetapi tidak berpengaruh terhadap berat volume tanah, pori drainase lambat dan hasil berat kering pipilan jagung; dan 3) Interaksi kompos granul ela sagu dan fosfat berpengaruh nyata terhadap jenis butiran tanah dan porositas, sedangkan dan fosfat berpengaruh nyata terhadap jenis butiran tanah.

\section{UCAPAN TERIMA KASIH}

Penulis menyadari sepenuhnya bahwa terselesainya penulisan ini berkat kasih dan anugerah dari Tuhan YME, juga dorongan dari berbagai pihak, baik moril maupun material, untuk itu melalui kesempatan ini penulis ingin menyampaikan rasa terima kasih yang tak terhingga kepada: Rektor Universitas Pattimura beserta Staf, Rektor Universitas Brawijaya beserta staf, Direktur Program Pascasarjana beserta staf, Dekan Fakultas Pertanian Universitas Pattimura beserta staf, Dekan Fakultas Pertanian Universitas Brawijaya beserta staf, Promotor dan Co-promotor serta Kepala Laboratorium Kimia, Fisika Tanah dan Biologi Tanah, Fakultas Pertanian Universitas Brawijaya Malang dan staf serta berbagai pihak yang telah banyak membantu penulis selama analisis dan penulisan jurnal ini.

\section{DAFTAR PUSTAKA}

Baver, L.D., W.H. Gardner \& W.R. Gardner. (1972). Soil Physics. 4th. Ed. John Wiley. New York.

Blake, G.R. (1986). Particel Density P. 377-382. In: Methods of Soil Analiysis. Part 1. Second ed. Agron 9 Am. Soe. Of Argon. Madison, W1.

De Fretes, P.L, R.W. Zobel \& V.A. Sneder. (1996). A Method for Studying the Effect of Soil Aggregate Size and Density. Soil. Sci. Soc. Am. J. 60: 288- 290.

Darmawijaya, M.I. (1990). Klasifikasi Tanah. Penerbit Universitas Gajah Mada. Yogyakarta.

Gregorich, E.G., D.A. Angers, C.A. Cambell, M.R. Carter, C.F. Drury, B.H. Ellert, P H. Groenevelt, D.A. Hlomtorm, C.M. Monreal, H.W. Rees, R.P. Voroney, \& T.J. 
Prosiding Seminar Nasional Pembangunan dan Pendidikan Vokasi Pertanian

Politeknik Pembangunan Pertanian Manokwari, 31 Juli 2021

e ISSN : 2774-1982

DOI : https://doi.org/10.47687/snppvp.v2i1.168

Vyn. (2002). Changes In Soil Organic Matter. Agricultura and Agri-Food Canada.

Gunadi, Soenarto \& T. Sudyastuti. (2005). Dinamika Ketersediaan Bahan Organik Dari Residu Pupuk Pupuk Hijau Daun dan Kompos Dalam Kaitannya Dengan Fisik Tanah Pasiran Di Lahan Pantai.

Hairiah, K.; Widianto; Utami, S.R.; Suprayogo, D.; Sunaryo; Sitompul, S.M.; Lusiana, B.; Mulia, R.; van Noordwijk, M. \& Cadish, G. (2000). Pengelolaan Tanah Masam Secara Biologi. International Centre for Research in Agroforestri. Bogor.

Hardjowigeno, S. (2003). Ilmu Tanah. Penerbit Akademika Pressindo-Jakarta.

Hillel, D. (1996). Introduction to Soil Physics. Terjemahan: Pengantar Fisika Tanah. Penerjemah: Susanto.R.H \& R. N. Hamidawati. Mitra Gama Widya.

Hinsinger, P. (2001). Bioavailability of soil inorganic P in the rhizosphere as affected by root-induced chemical changes: a review. Plant Soil 237:173-195.

Hinsinger, P., Bengough, A.G., Vetterlein, D., \& Young, I.M. (2009) Rhizosphere: biophysics, biogeochemistry, and ecological relevance. Plant Soil 321: 117-152.

Islami, T. \& W.H. Utomo. (1995). Hubungan Air, Tanah dan Tanaman. IKIP Semarang Press.

Jacob. (1992). Pengaruh Aktivator Terhadap Laju Dekomposisi dan Kualitas Kompos dari Limbah Organik Taman Safari Indonesia. Program Pasca Sarjana. IPB Bogor.

Kaya, E. (2003) Perilaku Fosfat Dalam tanah, Serapan Fosfat, dan Hasil Jagung (Zea mays L.) Akibat Pemberian Pupuk Fosfat dengan Amelioran Pada Typic Dystrudepts. Disertasi. Unpad. Bandung.

Kertonegoro, B.D. (2001). Aerasi Tanah dan Peranannya Bagi Tanaman. Jurusan Ilmu Tanah Fakultas Pertanian Universitas Gadjah Mada. Yogyakarta.

Marsono \& P. Sigit. (2005). Pupuk Organik dan Aplikasinya. Penebar Swadaya, Jakarta.

La Habi, M., Z. Kusuma \& Widianto. (2007). Kajian Cara Pemberian dan Dosis Ela Sagu Terhadap Erosi Tanah, Limpasan Permukaan Serta Pertumbuhan dan Hasil Jagung di Ultisol. http://ppsub.ub.ac.id/perpustakaan/abstraksi/tesis.

La Habi M. (2007). Pengaruh Cara Pemberian Dan Dosis Ela Sagu Terhadap Pertumbuhan dan Produksi Jagung Pada Ultisol. Jurnal Budidaya Pertanian Vol 3 (2).pp : 134-140.

Richardson, A.E., Barea, J.M., McNeill, A.M., \& Prigent-Combaret, C. (2009) Acquisition of phosphorus and nitrogen in the rhizosphere and plant growth promotion by microorganism. Plant Soil 321: 305-339.

Silahooy, C.H. (1999). Beberapa Sifat Fisik Tanah, Kehilangan Air Oleh Aliran Permukaan, dan Vertikal, Erosi Tanah, dan Hasil Jagung (Zea mays. L) Pada Tipic Paleudults yang Diberi Ela Sagu Beberapa Dosis dan Cara Pemberiannya. 
Prosiding Seminar Nasional Pembangunan dan Pendidikan Vokasi Pertanian

Politeknik Pembangunan Pertanian Manokwari, 31 Juli 2021

e ISSN : 2774-1982

DOI : https://doi.org/10.47687/snppvp.v2i1.168

Tesis. Fakultas Pertanian Program Studi Ilmu Tanah Universitas Padjadjaran Bandung.

Soemarno. (2002). Prinsip-Prinsip Pengelolaan Sumberdaya Alam dan Lingkungan. Program Pascasarjana Universitas Brawijaya Malang.

Soemarno, Sudarto, \& M.M. Mustadjab. (2009). Pengelolaan Sumberdaya Lahan Berkelanjutan. PM.

Stevenson, T.S. (1982). Humus Chemistry, Genesis Composition, and Reaction John Wiley and Sons. New York. 433 pp.

Widianto; Noveras, H.; Suprayogo, D.; Purnomosidhi, P., \& M. Van Noordwijk. (2004). Konversi hutan menjadi lahan pertanian; "Apakah fungsi hidrologis hutan dapat digantikan agroforestri berbasis kopi”. Agrivita 26 (1) : 47-52.

Winarso, S. (2005). Kesuburan Tanah: Dasar Kesehatan dan Kualitas Tanah. Penerbit Gaya media. Yogyakarta.

Wissuwa, M., Mazzola, M., \& Picard, C. (2009) Novel approaches in plant breeding for rhizosphere-related traits. Plant Soil 321: 409-430.

Zhang, F., Shen, J., Zhang, J., Zuo, Y., Li, L., \& Chen, X. (2010) Rhizosphere processes and management for improving nutrient use efficiency and crop productivity: implications for China. Adv Agron 107: 1-32. 